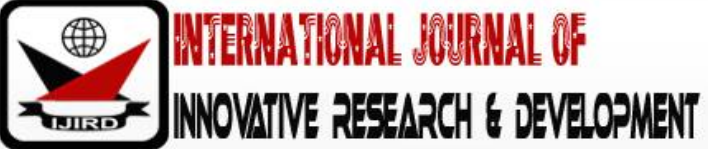

ISSN 2278-0211 (Online)

\section{Sociall Movement Strategy and the Composition of Modern African Plays}

\author{
Dr. Olusegun Osayomi \\ Associate Professor, Department of Languages and Literary Studies, \\ Babcock University, Ogun State, Nigeria \\ Sunday Agboola Olatunji, \\ Ph.D. Student, Department of Languages and Literary Studies, \\ Babcock University, Nigeria \\ Dr. Babatunde O. Adebua \\ Head, Department of Languages and Literary Studies, \\ Babcock University, Nigeria
}

\begin{abstract}
:
Modern African plays with radical bent appropriate social movement strategy in their attempts to interrogate the socio-political problems in Africa. Extant research on these plays focus mainly on their functionality, beauty and relevance without particular attention paid to their employment of social movement strategy which is central to their composition. This study interrogates the appropriation of social movement strategy in modern African drama, and the interface between the appropriation and the composition of it. Tess Onwueme's Then She Said It (2016) is adopted for explication of these. It is discovered that modern African drama with radical bent appropriates social movement strategy; that the appropriation dictates the use of collective heroism; that this enables the playwrights to examine the various socio-political problems in more radical perspectives; and that because of the appropriation characters are divided into two groups of social movement participants and social movement targets. The study concludes that the composition of plays using social movement strategy possesses the inherent potentials to shock the African people into new awareness that can lead to the creation of a just and virile society in Africa.
\end{abstract}

Keywords: Social Movements, social movement strategy, modern African drama, collective heroism, movement participants, move-targets

\section{Introduction}

Many researchers in the area of modern African drama have argued that the drama is functional. Such researchers include Osundare (2000), Ngugi (2007), Adedoja (2010) and Chinweizu et al (2016). The drama, apart from the primary purpose of entertainment, interrogates the various socio-political challenges, which have become the bane of Africa, with the aim of creating a just and virile society in Africa. It is with this idea in mind that Baharti et al posit that African drama '...has had a major impact on the society'(2). In the attempts to fulfill this lofty aim, modern African dramatists have employed and deployed various compositional strategies. African dramatists have experimented with strategies like poor theatre, total theatre, epic theatre, individual heroism, collective heroism.

One outstanding strategy that has been appropriated by African dramatists, especially by those commonly referred to as writing radical plays (Osofisan 2001, Gikandi 2002, Obafemi 2008, Emesealu 2011, Fashina 2019), is social movement strategy. Social movements involve collective action embarked upon by groups that feel disadvantaged against the privileged groups operating within the same socio-political spaces. They have been described as the 'organizational structures and strategies that may empower the oppressed populations to mount effective challenges and resist the more powerful and advantaged elites' (Deric 2011). A social movement is characterised by (1)'a network of informal interactions between plurality of individuals'; (2) 'engaged in a political or cultural conflict'; and (3) 'on the basis of shared collective identity' (Diani 1992).

Most researchers on the modern African drama, with radical bent, have focused on its functionality and its characteristic as protestant (Gbilekaa 1997, Benabai 2012, Owonibi 2014, Yakubu 2015, Adesuyi 2017, Gunner and Schaub 2019) with no particular attention paid to he drama's appropriation of social movement strategy which is central to the composition of it. The present study therefore interrogates the employment of social movement strategy in modern African drama and its impact on the composition of the drama as expressed in Tess Onwueme's Then She Said It (2016).

The use of 'modern' in the consideration of African drama in this paper is only meant to differentiate between the pre-colonial African drama, which is predominantly oral, from the postcolonial African drama, oral or written, which is a fusion of African and European compositional modes, but which content reflects and reflects upon, African experiences 
from the advent of colonialism to the present day. Thus, modern African drama is the study of the origin and development of postcolonial drama in Africa.

\section{Concept of Social Movement}

Social movement is multidimensional. It is difficult to have a clear-cut definition of it that would comfortably tallies with the various approaches to it by different scholars in the field. That is why Opp (2009) insists that 'There is no simple consensus definition of a social movement'. Thus, there are various definitions of social movements depending on the angle from which each scholar views it. Deric (2011) posits that social movements are 'organisational structure and strategies that may empower the oppressed populations to mount effective challenges and resists the more powerful and advantaged elites'. This definition considers social movement as an organised group action embarked upon by the oppressed to effect positive changes in status. Tilly (2004), however, contends that 'social movements are a series of contentious performances which may be spontaneous, displays and campaigns by which ordinary people make collective claims on others'. De La Porta argues that social movements 'involved conflictual relations with clearly identified opponents, who are linked by dense informal networks; and they shared a distinct collective identity'; and Diani (1992) avers that 'social movements are defined as networks of informal interactions between plurality of individuals...'.

To an extent the definitions of social movement by Diani, De La Porta and Tilly (2006) are slightly at variance with that of Deric above. Deric emphasizes formal organisations for social movements, while the others are of the opinion that social movements could be informal and spontaneous. However, it is essential to note that a social movement may be an informal phenomenon at the beginning but management and organisation become necessary when the individuals have come together in a collective action, otherwise achieving its goal may be difficult. This informs the Encyclopedia Britannica's submission that social movement is a '... loosely organised but sustained campaign in support of a social goal.'

Although there are many definitions of social movements from different scholars in the field; there are certain observable criteria that are common to all of them. Every definition of social movement agrees that social movements involve collective action; that they involve conflict, which may be political, social or cultural and that they are driven towards common goals. This is why Diani (1992) reiterates that all definitions of social movements share the following three criteria: (1)'a network of informal interactions between a plurality of individuals, groups or organisations, (2) engaged in a political or cultural conflict, and (3) on the basis of a shared collective identity.' (14). Thus, a social movement can be defined as a group or collective action embarked upon by a people who are brought together by a feeling of certain injustice, and so engaged in a political or cultural conflict against the perceived perpetrator(s) of the injustice with the main goal of redressing the injustice.

\section{Social Movement Strategy and Modern African Drama}

Social movements usually emerge in response to cultural and socio-political issues within societies. They are usually engaged in by a section of a society, corporation, and other organisations, which feels being oppressed or cheated. They involve collective actions in which a people who feel it is being oppressed makes claims against others. Even though there is no single consensus definition of social movements (Opp 2019), Diani (1992) posits that nearly all definitions of social movements share three criteria: (1) 'a network of informal interactions between a plurality of individuals, groups and, or organisations,' (2) 'engage in a political or cultural conflict;' and (3) 'on the basis of a shared collective identity'.

In the modern world, engagement in social movements has become one of the civilised ways of seeking justice where there is perceived injustice or the pressing for things that would be beneficial to the generality of people or even humanity. The main issue about social movements is change. Social movements may be embarked upon to cause change or to resist change. In line with this, Little and McGivern (2013) postulate that

social movements are purposeful, organised groups striving to work towards a common goal.

These groups might be attempting to create change (Occupy Wall Street, Arab Spring), to resist change (anti-globalisation movement), or to provide a political voice to those otherwise disenfranchised (civil rights movements). Social movements create social change.

In Africa, social movements have been used to create or resist change. The types of social movement appropriated in Africa ranged from reformative movements, which are mild and do not involve armed struggle (a good example is the recent workers strike in Nigeria to raise national minimum wage from $N 18,000=$ to $N 30,000=$ ), to radical movements which may involve violent resistance. Radical movements were used in Africa, especially during the Arab Spring and the struggle to free African nations from colonialism and apartheid. On the struggle for independence, Talton (2019) describes the radical movements embarked upon by Africans in Portuguese colonies, South Africa and Kenya thus:

In these territories, violent resistance brought colonial rule to a close. It was guerrilla warfare

in the case of Mau Mau Uprising in Kenya (1952 - 1960) and Zimbabwe's war of independence

(1965 - 1979); it was all-out war in the Portuguese colonies of Mozambique, Angola, Cape

Verde and Guinea Bissau (1961 - 1974), and South Africa colony of South West Africa

(Namibia).

The strategy of social movements has a process. The process starts with emergence and terminates with decline: Emergence $\rightarrow$ Coalescence $\rightarrow$ Bureaucratization $\rightarrow$ Decline (De la Porta (2006), Christiansen (2009), Macionis (2001). Modern African drama has appropriated social movement strategy and its processes. Right from the anti-colonial days, social movement strategy has been adopted in modern African drama. In West African region, plays that appropriate social movement strategy include Hubert Ogunde's Strike and Hunger (1945), Tiger's Empire (1946), Bread and Bullet (1950), Bode Sowande's Farewell to Babylon (1979), Flamingo (1986), Afamako-the Workhorse (1986), Circus of Freedom Square (2010), Ajantala Pinocchio (2011), Niyi Osundare's The State Visit (2002), Dauda Enna's Banquet of Treachery (2012), Femi 
Osofisan's Morountodun (1982); Ifechi Jane Odoe's Edge of the Brink (2016); Akanji Nasiru's The Rally (2018), Tess Onwueme's Then She Said It (2016); Elaigwu Ameh's Sweet Taste of Shame (2014).

There are so many other plays in this category from the West African region. Apart from Hubert Ogunde who uses his plays to attack the orientation and workings of colonialism, all the other playwrights use their plays for conscientization purposes to move the African people into collective actions against oppression, repression, impoverishment by the neo-colonial rulers in Africa who collude with foreigners to cause problems for the masses and retard the social, political and economic progress of Africa and its people.

In Central Africa, social movement strategy is employed in modern African drama. The plays in this cohort include Bole Butake's And Palm Wine Will Flow (2013); and plays of Bate Besong like Beasts of No Nation (2003). These plays adopt social movement strategy to condemn and fight internal colonialism, corruption, bad leadership and so on.

East African region is as vast and dynamic as West African region in the appropriation of social movement strategy in drama. The leading dramatists in this region who adopt social movement strategy include Ngugi wa Thiong'o and Micere Githae Mugo in the collaborative play titled The Trial of Dedan Kimathi (1990); Ngugi wa Thiong'o and Ngugi wa Mirii in I Will Marry When I Want (reprinted 2005). Other playwrights include Ebraim Hussein in Kinjeketile (1972), Desmond Phiri in Let Us Fight for Africa (2008); Mukotani Rogyendo in The Barbed Wire (1977). These playwrights use social movement strategy in their plays to conscientise the people, to galvanise the oppressed to rise against their oppressors, and to condemn corruption and the class stratification of the society. Kerr, writing about the creation of Ngugis, I Will Marry When I Want, informs that

the whole play creation process was not really that of a conventional literary text. By June 1977 the Ngugis had written a draft of Ngaalhi Ka Ndeenda (I Will Marry When I Want) which had the stamp of Ngugi wa Thiong'o's characteristic pre-occupation - class conflict, the seduction of a woman as a metaphor for exploitation, and the comparison between the struggle against colonialism and the post-independence struggle against neocolonialism (243).

In Southern African nations improvised plays, performed drama texts, dramatised songs have been used for struggle against colonialism. Many of these employ collective action or social movements in their plots. Musical plays like Sarafina! by Mbongeni Ngema (the musical drama was turned into a movie) uses social movement strategy: students in a secondary school rise against oppression of blacks in apartheid South Africa. Andrea Beach, in an online review of the film version of the musical, emphasizes the necessity for social struggle today. He posits that the musical play is 'about how to achieve social justice and about how oppression and rebellion are sadly as relevant today... ' Southern Africa nations, because of their similar experiences and their armed struggle against agents of colonialism and apartheid, adopt social movement strategy in their dramatic works, whether improvised or written. In the sixties, Southern African nations like South Africa, Angola, Zimbabwe formed alliances which involved military training and assistance.

The alliances were possible because of the similarities in the nations' socio-political experiences. African National Congress (ANC) of South Africa, People's Movement for the Liberation of Angola (MPLA), South West People's Organisation (SWAPO), Zimbabwe Party for the Independence of Guinea and Cape Verde (PAIGC) entered into military alliance (Dreyer 1994). Of the alliance of South Africa freedom fighters with those of Zimbabwe, Oliver Thambo, quoted in Scott Thomas recalls:

We have had political relations with ZAPU, and these developed into relations at military level, until we were in position to fight together. This close alliance is first of its kind one can recall in the liberation movement. In no previous instance has there actually been fighting by freedom fighters drawn from different territories.

Thus, the use of social movements as a tool for liberation and freedom is common to Southern African nations. This has influenced many of the dramatic activities from the region because 'Drama imitates men in action' (Dada 1994).

In different refugee camps in Southern Africa, plays with the orientation of struggle involving the appropriation of social movement strategy and history were produced for the purposes of conscientization, education and entertainment. Examples of such plays are Soweto Flowers Will Grow, a 'trilogy... created by Masantso Phiri and the Tikwiza Theatre in Lusaka (1977-9)' (Kerr 235); and Freedom in Our Own Lifetime. This play adopts collective heroism motif common with plays that appropriate social movement strategy. According to Kerr (1997), 'the sense of collectivity also applied to the characterisation (in the play) since the play presented 'the story of a people".

Today, there are so many playwrights from Southern Africa. Notable among them are Athol Fugard, John Kani, Mbogeni Ngema, Olando Mendes, Michael Usi, Innocent Banda, Magi Williams and so many others. Their plays 'were written with relevant themes of oppression, exploration and exploitation in its relative theme of corruption (buttressing) the debilitating effects of colonialism.' Many of their plays have appropriated social movement strategy. Such include Zakes Mda's Fools, Bells, and the Habit of Eating (2002) and Magi William's Kwa-Landlady (1998).

Northern Africa, like other regions of Africa, experienced colonialism with its resultant disruptions of people's culture, philosophy, social and political life. Modern African drama in the region reflects, and reflects upon, these cultural and socio-political anomalies within the region for the main purpose of their rectification. Most of the modern literary works from Northern Africa are mainly written in French and Arabic (languages of their colonial masters), very few in English. Some of these works have been translated into English. According to Encyclopedia.com, 'North African writers convey their ideas (mainly) in French and Arabic in a variety of literary genres.'

Important playwrights from the region include Tewfik Al-Hakim, AbdelKader Alloula, Jalila Baccar, Tayeb Saddiki, Nawal El Saadawi. North African region is noted for protests against bad leadership, corruption, authoritarianism, religious fundamentalism and other vices. One notable protest in this line is Arab Spring. With this, it is expected that modern North African drama should contain protest plays as drama records the actions and interactions within the society 
that produces it. Some of the protest plays appropriate social movement strategy. One important playwright from the region whose protest plays, seven of them, stand out is Nawal El Saadawi. Her plays Isis and God Resigns at the Summit Meeting (translated 2009) adopt social movement strategy.

The survey has indicated that both in real life situations and in drama and literature social movements are used as means of insisting on, or resisting, changes. Social movements have been appropriated in all the five regions of Africa and modern African drama has reflected this. All the six plays selected for analysis in this study have used one form of social movement or the other.

\section{Social Movement Strategy and the Composition of Tess Onwueme's Then She Said It}

The employment of social movement by the text dictates certain compositional structures. The first major structural change noticed in the text and others like it is with characterization. The play employs collective heroism because social movements require at least two groups: movement participants and movement target(s). The movement participants feel deprived or observe some injustice which must be addressed. This is always the case with fraternal relative deprivation in which comparison is possible between groups (Taylor 2019).

While the movement targets, the neo-colonial forces, hold tenaciously to the wealth of Hungeria and are not ready to share or make the majority of the people enjoy, the movement participants, the masses of Hungeria, complain bitterly about their situation and the wickedness of the neocolonial forces:

Obida: And did you hear how much the so-called leaders spent renovating their mansions in the state capital

Women: No. Tell us.

Obida: Billions!

Women (Alarmed.): Ehn?

Obida: Enough to feed this nation for centuries!

Niger: And here we are.

Benue: Begging.

Obida: Just to be able to survive.

Women: And look around you. See? They're not even killing us alone. The trees too!

Niger: Our farmlands!

Benue: Rivers!

Niger: The environment! (15)

The adoption of collective heroism in the play, and others of the same revolutionary bent, is a departure from earlier compositional structure of individual heroism employed in many plays by dramatists like Wole Soyinka, Zakes Mda, Tewfik Al-Hakim and others from Africa.

The use of collective heroism has also enabled the text to depict the struggle that results from the stratification of the society into high and low classes. In Marxist term, the government officials like Kainji and Chief Ethiope, representing traditional rulers and institutions in Hungeria, are the bourgeois. This is because they control the means of production while the masses, the lower class, are the proletariat. The GRA/Oil Club and the Market are used as motifs to represent this idea. The GRA/Oil Club symbolically represents evil as it is used as a converging point for the neocolonial forces to determine, and scheme, how more money or wealth would come to them at the detriment of the masses. The market, on the other hand, symbolizes the place of the masses, an alternative, and more humane society to the vampirish one of the GRA/Oil Club. Within this alternative society, sisterly love reigns supreme and everyone cares about the good of the community, unlike in the GRA/Oil Club where, in spite of the flow of wealth to the club, the postcolonial forces still scheme to betray one another. For example, Kainji wants to scheme out Chief Ethiope of a business deal in this dialogue:

Kainji: You know that man is... is funny?

Atlantic: Which man?

Kainji: The Chief, you know.

Atlantic (Scribbling at a signpost.): Hmmm... Oh yes! Oh yes!

Kainji: You trust him?

Atlantic: Hnm?

Kainji: You do.

Atlantic (Pretending.): What?

Kainji: I say do you trust the Chief?

Atlantic (Smilling.): Oh that? (Hesitates.) Yeah as much as the weather $(37-38)$.

At other time, Chief Ethiope too wants to scheme out Kainji, the government official, so as to ensure he gets more money:

Chief (Coughs.): These Government Officials! Never trust them.

Atlantic: True? I've heard that a billion times.

Chief (Whispering.): I tell you be careful.

Atlantic: But why precisely?

Chief: They're greedy. Oh, so greedy! (Coughs, adjusts his seat.) Government workers working for themselves. Ha! $\mathrm{Ha}$ ! Ha!

Atlantic (Laughing.): You all... I know. Ha!

Chief: That's why you must listen to me. (Pause.). You see that new place by my village where you just struck a new oil well? (ATLANTIC is silent) (40-41). 
Also, the adoption of collective heroism in the text has made it possible for the play to have a kind of feminist orientation. The feminist orientation is somehow forced and tending towards ridiculousness. All the negative, wicked and corrupt characters in the text are male, while all the movement participants who are seeking for justice and fair play are female, except for two other boys, Oji and Kainji, who, beyond reasonable explanation, also double as members or operatives of the neocolonial forces impoverishing the people. Oji, at a point in time, plays the part of a disgruntled white priest $(34-36)$, and at other time as an illiterate and wicked police officer enforcing the notorious laws of the military regime under General. Kainji also plays the part of the roguish Government Official (3-8, 56-58), a police officer (18-22).

Another thing is that the major movement participants are women. A good reader would want to ask where are the men of the community? The social movement in the play is carried out from the emergence stage through the decline stage and everything is about women. The women only mention problems faced by men in their discussion. The characters in the following dialogue are all women but they talk about the problems of men and the people:

Benue: Ever since they discovered oil in our land, they drill, dry and fry us alive with the fishes and farmlands all cooking in the oil.

Chorus: The oil. Our oil.

Benue: So, what will become of us... our children? (Pause.) Do you smell the decaying bodies of our husbands, sons and daughters?

Chorus: Yes!

Benue: Do you smell the fishes roasting in their hot oil poured over the rivers?

Chorus: Yes! They've refined our oil into a curse!

Benue: Where? Where else in the world does oil cease to anoint?

Chorus: Here! Here! Here!

Benue: Plants, animals, children, men, women cooking in their oil. Oil sapped from the very soul of our sagging land. Ah! People of the delta! Do you see yourselves drowning?

Chorus: Yes!

Benue: Starving?

Chorus: Yes!

Benue: Wilting?

Chorus: Yes!

Benue: What then are you waiting for, mothers, sons and daughters (In this, fury, the mob rises, facing the direction of the GRA/Oil Club.)

Chorus: Nothing! Nothing! No more waiting.

Benue: I do not wish to speak for you or for anybody. Let every woman speak for herself. And in the end tell us women, what are we going to do? (77 - 78).

There is nothing wrong with creating strong female characters like Titubi in Osofisan's Morountodun (1982), Jolomitutu in Sowande's Farewell to Babylon (1979), or Isis in El-Saadawi's Isis (2009). These plays still have strong or weak male characters to reinforce the strength in the strong female characters. However, it is tendering towards ridiculous extremity to have almost all female characters as movement participants in a text that focuses on one of the most devastating postcolonial problems in Nigeria.

Use of collective heroism has also given the text better opportunity to depict and analyse the problematic power relations within neocolonial states. Collective heroism which involves collective actions gives voice and power to the masses and they push forward to challenge and invade the centre of power as controlled by the neocolonial forces which dehumanize and impoverish the people. The interaction between the oppressed and their oppressors helps to focus the various postcolonial problems in more radical perspective. The problems include massive unemployment. When Atlantic advertises for just one guard, millions of the down pressed masses bombards his gate seeking to be his guard.

Atlantic: My Gaaaaad! Look. The whole damned country is at the gate. Waiting. Waiting for handouts! (Signs.)

Kainji: But it's only one job.

Atlantic: Just one vacancy for a guard. And they're all here? The whole nation? One hundred and twenty million of them? (58).

The desperation indicates the level of people's poverty in the neocolonial state.

Other problems in the nation include bribery and corruption. The elites bribe their way out to get whatever they want, including justice. With this, corruption becomes endemic. The people complain about their oppressors:

Obida: Thief!

Women: Tief! Oleh! Oshi! Barawo!

Obida: Yes. That's how you people hike up everything

Niger: So poor people no go get.

Obida: You create artificial scarcity.

Women: To cheat us (20).

Greed and corruption lead to much killings of the people.

\section{Conclusion}

The paper has examined the concept of social movement and its strategy; the interface between social movement strategy and modern African drama; the appropriation of the strategy in modern African drama and how this has impacted on the composition of the drama. The paper has analysed Tess Onwueme's Then She Said It (2016) to illustrate how the adoption of social movement strategy has assisted in the examination of the various socio-political problems in Africa in a 
more radical perspective, and how this has affected the composition of the play. The appropriation of social movement strategy in the play has dictated the use of collective heroism, a technique which aligns with social movement that involves the presence of two disparate groups interacting within a social space. This type of composition has the inherent potentials to shock the African people into a new awareness which can lead to creating a better society in Africa.

\section{References}

i. Adesuyi, C. (2017). Thematic preoccupation of Nigerian literature: A critical approach. D0I:10.5430/elr. v6n3p22

ii. Ameh, E. (2014). Sweet taste of shame. Ibadan: UPL.

iii. Baharti, K., and Jiwaji, S. A. (2015). The role of English literature in re-construction society. Journal of Culture, Society and Development, vol. 7, pp. $1-4$.

iv. Benebai, Benedict (2013). Protest premise in drama and theatre of Africa: A spotlight on cultural nationalism. The Dawn Journal, vol. 2, issue 2, pp. $366-373$.

v. Besong, B. (2003). Three plays: The achiwingbe trilogy. Yaounde: Editions CLE.

vi. Butake, B. (2013). Dance of the vampire and six other plays. Yaounde: Longman Research \& Publishing C/G.

vii. Chinweizu, O. J., Onwuchekwa, J. \& Ihechukwu, M. (2016). Towards the decolonisation of African literature. Enugu: ABIC Books,

viii. Deric, Shannon (2011). Political sociology: Oppression, resistance and the state. California: Pine Forge Press,

ix. Diani, Mario (1992). The concept of social review. The Sociological Review, vol. 40, no. 1, pp. 1 - 25.

x. Emesealu, E. C. (2011). Drama and social change: A study of select plays of Bode Sowande. Culture and Religion Review Journal, vol. 20, no. 1, pp. $14-22$.

xi. Enna, Dauda (2012). Banquet of treasury. Ibadan: Kraft Books.

xii. Fashina, Nelson (2009). Alienation and revolutionary vision in East African post-colonial dramatic literature. Ufarhamu: A Journal of African Studies, vol. 35, no. 2. Retrieved from scholarship.org/uc/item/63K8d46k. Accessed 16 March, 2019.

xiii. Gbilekaa, E. T. (1997). Radical theatre in Nigeria. Ibadan: Caltop Publication.

xiv. Gikandi, Simon (editor) (2003). Encyclopedia of African literature. London: Routledge.

xv. Gunner, W.A.E. \& Scheub, H. 'African Literature.' https://www.Britannica.com/art/African-literature. Accessed 02 June 2019.

xvi. Hussein, E. (1972). Kinjekitile. Dar es Salaam: OUP.

xvii. Mda, Z. (2002). Fools, bells and the habit of eating. Pretoria: Wits University Press.

xviii. Nasiru, A. (2018). The rally. Ibadan' Kraft Books.

xix. Ngugi, W. T. \& Muchere, M. (1976). The trial of Dedan Kimathi. Kenya: Zed Publishers.

xx. Ngugi, W. T. (2007). Writing against neo-colonialism. African literature: An anthology of criticism and theory, edited by Tejumola Olaniyan and Ato Quayson. New Jersey: Blackwell Publishing, pp. 98 - 111.

xxi. Obafemi, Olu (2008). Politics and aesthetics: Essays in drama, theatre and performance. Ilorin: Haytee Press and Publishing Co. Ltd.,

xxii. Odoe, I. J. (2016). Edge of the brink. Ibadan: Kraft Books.

xxiii. Onwueme, Tess (2016). Then she said it. London: Oxford University Press.

xxiv. Opp, K. (2009) Theories of Political Protest and Social Movements: A Multidisciplinary Introduction, critic and Synthesis. Oxfordshire: Routledge.

xxv. Osofisan, F. (1982). Morountodun and other plays. Ibadan: Longman Nigeria Limited.

xxvi. Osofisan, Femi (2001). 'Playing dangerously: drama at the frontiers of terror in a postcolonial state.' Insidious Treasons: Drama in Postcolonial State. Opon Ifa Readers, pp. 84 - 100.

xxvii. Osundare, N. (2012). The state visit. Ibadan: Kraft Books.

xxviii. Osundare, Niyi (2000). 'Caliban's gamble: The stylistics repercussion of writing African literature in English.' Language in Nigeria: Essays in honour of Ayo Bamgbose, edited by Kola Owolabi. Group Publishers, pp. 52 - 58.

xxix. Owonibi, Sola (2014). The political consciousness in African literature: A reading of selected plays of Femi Osofisan. European Scientific Journal, vol. 10, no. 20, pp. 289 - 296.

xxx. Sowande, B. (1979). Farewell to Babylon and Other Plays. Ibadan: Longman.

xxxi. Sowande, B. (1986). Flamingo and other plays. Ibadan: Longman.

xxxii. Sowande, B. (2011). Ajantala pincchio. Ibadan: Book Builders.

xxxiii. Talton, B. (2019). African resistance to colonial rule. Schaumburg Centre for Research in Black Culture. Accessed 23 May, 2019.

xxxiv. Williams, M. (1998). Kwa-Landlady. Black South African women: An anthology of plays edited by Karthy A. P. London: Routledge, pp. 162 - 176.

xxxv. Yakubu, M. A. (2015). Contemporary African literature and the concern over bad governance in Nigeria: A study of Olu Obafemi's Naira Has No Gender and Femi Osofisan's Morountodun. American International Journal of Contemporary Research, vol. 5, no. 5, pp. 77 - 83. 